\title{
CAMA
}

Centre for Applied Macroeconomic Analysis

\section{Growth in International Commodity Prices, the Terms of Trade, and GDP per capita: A Case Study of Vietnam}

\section{CAMA Working Paper 54/2016 September 2016}

\section{Markus Brueckner}

Research School of Economics, ANU and

Centre for Applied Macroeconomic Analysis, ANU

\section{Kien Trung Nguyen}

Da Nang University of Economics

\begin{abstract}
The Vietnamese economy is characterized by a high degree of international trade openness and a relatively low GDP share of net-exports. This paper examines the effect of growth in the terms of trade, and more specifically, in international commodity prices, on Vietnam's GDP per capita growth. The paper finds that, during 2000-2014, growth in the terms of trade contributed positively to Vietnam's GDP per capita growth but the effect is not large: less than one-tenth of Vietnam's GDP per capita growth was due to growth in its terms of trade. The paper argues that the relatively small effect of growth in the terms of trade on GDP per capita growth is due to a low GDP share of net-exports. Econometric model estimates show that transitional convergence accounted for about half of Vietnam's GDP per capita growth during 2000-2014.
\end{abstract}




\section{Keywords}

\section{JEL Classification}

\section{Address for correspondence:}

(E) cama.admin@anu.edu.au

\section{ISSN 2206-0332}

The Centre for Applied Macroeconomic Analysis in the Crawford School of Public Policy has been established to build strong links between professional macroeconomists. It provides a forum for quality macroeconomic research and discussion of policy issues between academia, government and the private sector.

The Crawford School of Public Policy is the Australian National University's public policy school, serving and influencing Australia, Asia and the Pacific through advanced policy research, graduate and executive education, and policy impact. 


\title{
Growth in International Commodity Prices, the Terms of Trade, and GDP per capita: A Case Study of Vietnam
}

\author{
Markus Brueckner \\ RSE and CAMA Australian National University \\ and \\ Kien Trung Nguyen \\ Da Nang University of Economics
}

\begin{abstract}
The Vietnamese economy is characterized by a high degree of international trade openness and a relatively low GDP share of net-exports. This paper examines the effect of growth in the terms of trade, and more specifically, in international commodity prices, on Vietnam's GDP per capita growth. The paper finds that, during 2000-2014, growth in the terms of trade contributed positively to Vietnam's GDP per capita growth but the effect is not large: less than one-tenth of Vietnam's GDP per capita growth was due to growth in its terms of trade. The paper argues that the relatively small effect of growth in the terms of trade on GDP per capita growth is due to a low GDP share of net-exports. Econometric model estimates show that transitional convergence accounted for about half of Vietnam's GDP per capita growth during 2000-2014.
\end{abstract}




\section{Introduction}

The Vietnamese economy is a useful case study for demonstrating that the impact of growth in the terms of trade, and specifically of international commodity prices, on GDP per capita growth depends on the GDP share of net exports - and that trade openness, measured as exports plus imports over GDP, can be a misleading statistic. In a nutshell, the argument can be summarized as follows. First, note that $G D P=C+I+G+N X$. Totally differentiating this equation, one can see that the income gain of a change in the international price, $p$, of an exported commodity, $x$, is $\mathrm{d} \ln (G D P)=(x / G D P)^{*} \mathrm{~d} \ln (p)$; for an imported commodity, $m$, the effect is $\mathrm{d} \ln (G D P)=-$ $(m / G D P)^{*} \mathrm{~d} \ln (p)$. For a change in the international price of net exports, $N X$, the effect is $\mathrm{d} \ln (G D P)=$ $(N X / G D P)^{*} \mathrm{~d} \ln (P)$, where $P$ is the geometric sum of prices of exports and imports. Note that $N X / G D P=(N X / T R A D E) *(T R A D E / G D P)$. For a given ratio of net exports, $N X$, over imports plus exports, TRADE, an increase in trade openness increases the effect that growth in the terms of trade has on GDP per capita growth. However, ultimately it is the ratio of net exports that matters for the overall size of the income gain (or loss).

Vietnam is more open to international trade than the majority of countries in the world. The cross-country differences in trade openness are substantial. In 2010 Vietnam's ratio of exports plus imports over GDP was 150 percent. In that year, Vietnam's trade openness was twice that of the median country in the world. In 2010 the median country in the world had a ratio of exports plus imports over GDP of 80 percent. The country at the $75^{\text {th }}$ percentile had a ratio of exports plus imports over GDP of 110 percent. In 2010 Vietnam ranked in the top 10 percent of countries in the world with regard to international trade openness.

Figure 1 shows that since the 2000s the Vietnamese economy experienced a significant increase in trade openness. Between 2000 and 2010 the ratio of international trade in goods and services over GDP increased by 50 percent, from 100 percent in 2004 to 150 percent in 2010 . In the year 2014 trade openness in Vietnam was 170 percent of GDP. During this time period there was a significant increase in exports and imports. The GDP share of Vietnam's merchandise exports 
increased during the 2000s by 20 percentage points, from 40 percent in 2000 to 60 percent in 2010 . In 2014 the GDP share of merchandise exports was 80 percent. The GDP share of merchandise imports increased by 20 percentage points during the 2000 s, from 50 percent in 2000 to 70 percent in 2010. In 2014 Vietnam's GDP share of merchandise imports was 80 percent.

Figure 2 shows that Vietnam had a current account deficit for the majority of years during the 2000s. The average current account deficit during 2000-2010 was around 3 percent of GDP. In 2008, the peak year of the global financial crisis, Vietnam's current account deficit reached 10 percent of GDP. However, since 2011 Vietnam's current account displayed a surplus - amounting to about 4 percent of GDP.

Figure 3 shows that Vietnam's terms of trade peaked in 2010, and since then have remained at about the same level. Between 2000 and 2010 the net barter terms of trade increased by 30 percent.

\section{Vietnam's Commodity Exports and Imports}

In the early 2000s Vietnam was a net-exporter of fossil fuels but this changed throughout the course of the decade. In 2000 the GDP share of net-exports of fossil fuels was around 5 percent. Figure 4A shows that during the 2000s the GDP share of net-exports of fossil fuels declined significantly. By 2010 Vietnam had become a net-importer of fossil fuels. In 2014 the GDP share of net-imports of fossil fuels was around 0.5 percent. During the 2000s the share of fossil fuel exports in merchandise exports declined, and more so than the share of fossil fuel imports in merchandise imports.

During the 2000s the Vietnamese economy experienced an increase in the GDP share of netimports of metals and ores. This can be seen from Figure 4B. In 2000 the GDP share of net-imports of metals and ores was around 1 percent. By 2010 the GDP share of net-imports of metals and ores was around 3 percent. One can see that the increase in the GDP share of net-imports of metals and ores is due to a significant increase in the GDP share of imports of metals and ores. The share of 
imports of metals and ores in merchandise imports increased from 2 percent in 2000 to 5 percent in 2010.

Vietnam is a net importer of agricultural raw materials. Since 2000 there has been a gradual increase in the GDP share of net-imports of agricultural raw materials, see Figure 4C. In 2000 the GDP share of net-imports of agricultural raw materials was around 0.5 percent; by 2014 it was 1.5 percent.

Vietnam's GDP share of net-exports of food is large relative to other commodity bundles. However, as Figure 4D shows the GDP of net-exports of food has declined since 2000. In 2000 the GDP share of net-exports of food was 8 percent of GDP; by 2014 it was 5 percent. The GDP share of food exports remained stable during that time period at about 11 percent. The GDP share of food imports increased significantly, from 2 percent in 2000 to 7 percent in 2014. Figure 4D also shows that the share of food exports in merchandise exports declined since 2000 by around 10 percentage points: In 2000 the share of food exports in merchandise exports was around 25 percent; in 2014 it was 15 percent.

\section{Time Series of International Commodity Price Indices}

Figure 5 shows time-series plots of international commodity price indices. One can see that for all four price indices there has been a significant increase. During 2000-2014, the commodity with the largest price increase was oil. During that time period the international oil price increased by about 350 percent. The second largest price increase was in metals, ores, and minerals. The price index for metals, ores, and minerals increased during 2000-2014 by about 300 percent. The agricultural raw materials price index increased by 90 percent; and the food price index increased by about 250 percent. For the oil price index and the metals, ores, and minerals price index there were two significant peaks: one in the year 2008 and the other in the year 2012. The price indices of agricultural raw materials and food had one significant peak in 2012. 
A strict mathematical argument suggests that the impact of international commodity price growth on GDP growth depends on two factors: (i) the GDP share of net-exports of commodities; and (ii) the growth in the international prices. To see this note that $G D P=C+I+G+N X$. Taking natural logarithms of both sides and totally differentiating yields $\Delta \ln \left(G D P_{t}\right)=\delta_{t-1} * \Delta \ln \left(P_{t}\right)$, where $\delta_{t-1}$ is the GDP share of net-exports of commodities in period $t-1$ and $P_{t}$ is the international commodity price in period $t ; \Delta$ is the change between period $t$ and $t-1$.

Figure 6 shows time-series graphs of $\delta_{t-1} * \Delta \ln \left(P_{t}\right)$ for various commodity bundles of interest. One can see that for fuel and food the year-to-year growth rates of $\delta_{t-1} * \Delta \ln \left(P_{t}\right)$ are positive in the majority of years since 2000. During 2000-2010 the average predicted effect on Vietnam's GDP growth of growth in international fuel prices is around 0.6 percent per annum. For growth in international food prices the effect on GDP growth is around 0.5 percent per annum. For fuel, the largest positive effect is in the year 2005; in this year the international oil price increased relative to the previous year by over $0.3 \log$ points. The predicted effect of growth in international fuel prices on Vietnam's GDP growth in 2005 is around 1.5 percent. For food, the largest positive value is in the year 2008 when the international food price increased relative to the previous year by over 0.3 $\log$ points. The predicted effect on Vietnam's GDP growth in the year 2005 is around 2.3 percent.

During 2000-2010 the average predicted effect on Vietnam's GDP growth of growth in international prices of metals, minerals and ores is around -0.2 percent per annum. This reflects that Vietnam is a net-importer of this group of commodities and that during that time period the international prices of metals, minerals and ores increased on average. However, in the year 2008 the metals, minerals and ores price index declined significantly, by around $0.4 \log$ points. The decline in prices in metals, minerals and ores positively contributed to Vietnam's GDP growth in 2008. The predicted effect is sizable, amounting to about 1 percentage point.

Growth in agricultural raw materials prices during 2000-2010 had a relative small effect on GDP growth in Vietnam. The average predicted effect on GDP growth is around -0.05 percentage points. The peak growth in agricultural raw materials prices was in the year 2010, amounting to 
about $0.3 \log$ points. The predicted effect on Vietnam's GDP growth is around -0.2 percentage points in that year.

Figure 6 also shows that during 2011-2014 the contribution of growth in the international fuel and food prices on Vietnam's GDP growth is near zero. For fuel this reflects that during 20102014 Vietnam's GDP share of fuel net exports was around zero. For food the small contribution to Vietnam's GDP growth reflects that growth in international food prices during 2010-2014 was less than 1 percent per annum.

Figure 7 shows a time-series graph of $\delta_{t-1} * \Delta \ln \left(P_{t}\right)$ for the sum of the four commodity bundles. One can see that for the majority of years, the values are in the positive range. The average during 2000-2010 is around 0.8 percentage points per annum. This suggests that the impact on Vietnam's GDP growth of the international commodity price boom during the 2000s was positive. The peak effect is in the year 2008: the year-to-year changes in international commodity prices lifted Vietnam's GDP growth by around 2 percentage points. During 2011-2014 the effect of changes in the international commodity prices on Vietnam's GDP growth was around 0.15 percentage points per annum.

For the period 2000-2014, the average predicted effect of changes in international commodity prices on Vietnam's GDP growth is around 0.7 percentage points. To set this figure into perspective, it is useful to note that during 2000-2014 Vietnam's GDP per capita growth was around 5 percentage points per annum.

\section{Econometric Model}

The simplest econometric model of the impact of growth in the terms of trade on GDP per capita growth is:

$$
\text { GDPgrowth }_{\mathrm{t}}=\mathrm{a}+\mathrm{bTermsof} \text { Tradegrowth }_{\mathrm{t}}+\mathrm{e}_{\mathrm{t}}
$$

Least squares estimation of the above model, using data for Vietnam during 2000-2015, yields $b=0.14$. The Huber robust standard error associated with that estimate is 0.06 . Hence one can reject 
the hypothesis that growth in the terms of trade had no effect on GDP per capita growth at the 5 percent significance level.

During 2000-2015, the growth rate of Vietnam's terms of trade was around 2 percent per annum. Using a coefficient $b=0.14$ from the estimates of the econometric model, one can compute that GDP per capita growth was lifted during $2000-2015$ by around 0.3 percentage points per annum. Since GDP per capita growth was around 5 percent per annum during that time period, growth in terms of trade contributed less than one-tenth ${ }^{1}$ to Vietnam's GDP per capita growth.

A multivariate model is needed for decomposing economic growth into transitional convergence and other variables, $X$. Araujo et al. (2014) use the following econometric model:

$$
\ln \mathrm{y}_{c t}-\ln \mathrm{y}_{c t-1}=\varphi \ln \mathrm{y}_{c t-1}+\Gamma \ln (\mathrm{X})_{c t}+\mathrm{a}_{c}+\mathrm{b}_{t}+\mathrm{e}_{c t}
$$

where $\ln y_{c t}-\operatorname{lny}_{c t-1}$ is the change in the natural logarithm of real GDP per capita in country $c$ between period $t$ and $t-1 ; \operatorname{lny}_{c t-1}$ is the natural logarithm of real GDP per capita of country $c$ in period $t-1 ; a_{\mathrm{c}}$ and $b_{\mathrm{t}}$ are country and time fixed effects; and $\mathrm{e}_{c t}$ is an error term. The vector of growth determinants, $X_{c t}$, includes the natural logarithms of secondary enrolment, the GDP share of domestic credit to the private sector, trade openness, government size, telephones lines per capita, inflation, the real exchange rate, an indicator of systemic banking crises, and the growth rate of the terms of trade. Additional variables that are included in $\mathrm{X}_{\mathrm{ct}}$ are the Polity2 score, which is a measure of the degree of political competition and political constraints, as well as the growth rate of an international commodity export price index that captures windfalls from international commodity price booms.

The system-GMM estimates of the econometric model by Araujo et al. (2014) supports the key feature of neoclassical growth models of convergence in real GDP per capita. The estimated coefficient on lagged (log) GDP per capita is 0.78 and has a standard error of 0.06 . One can reject the hypothesis that the coefficient is equal to zero and unity at the conventional significance levels.

The econometric model estimates of Araujo et al. (2014) show that growth in the terms of trade has a significant positive effect on GDP per capita growth. The coefficient on the terms of 
trade is around 0.12 . One can reject the hypothesis that this coefficient is equal to zero at the 1 percent significance level.

Based on the Araujo et al. (2014) model estimates, Figure 9 plots the contribution of growth in the terms of trade and transitional convergence on Vietnam's GDP per capita growth. From Figure 9, one can see that during 2000-2014 transitional convergence accounted for more than half of Vietnam's GDP per capita growth. Growth in terms of trade had a positive effect on Vietnam's GDP per capita growth: about one-tenth of the observed GDP per capita growth during 2000-2014 was due to growth in the terms of trade. For comparison of the size of these effects to other natural resource exporting countries, see Araujo et al. (2014) or Brueckner and Hansl (2016). 


\section{References}

Araujo, J., M. Brueckner, M. Clavijo, E. Vostroknutova, and K. Wacker (2014). "Benchmarking the Determinants of Economic Growth in Latin America and the Caribbean." World Bank Publications, The World Bank, number 91015, December.

Brueckner, M. and B. Hansl (2016). "Drivers of Growth in Russia." ANU Working Papers in Economics and Econometrics 2016-640.

WDI (2016). World Development Indicators. Online database. 
Figure 1. Trade Openness
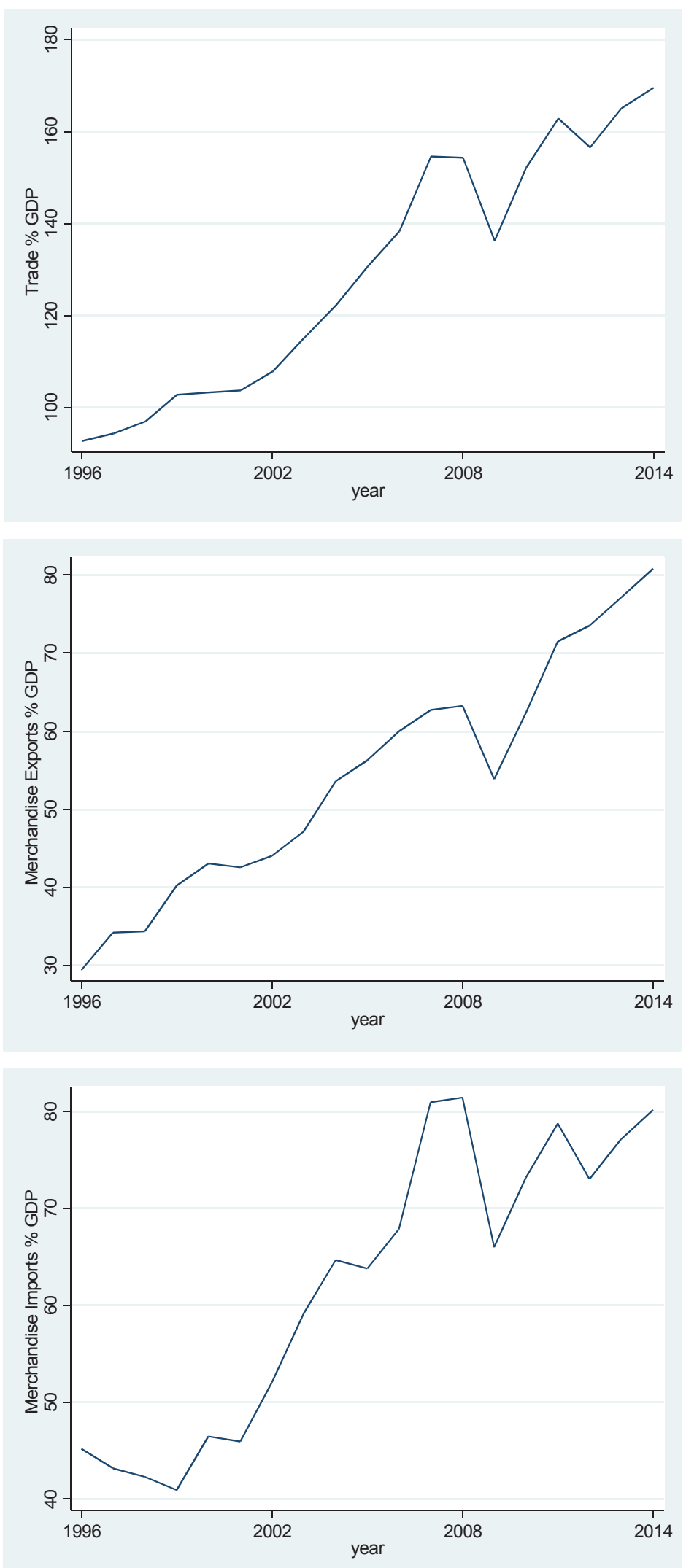
Figure 2. Current Account

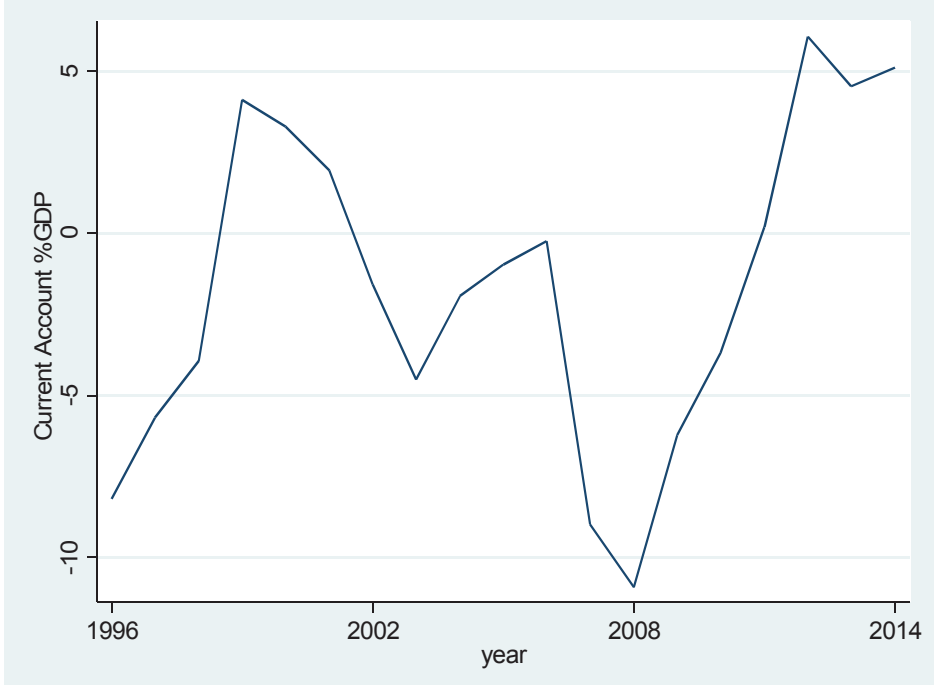


Figure 3. Net Barter Terms of Trade

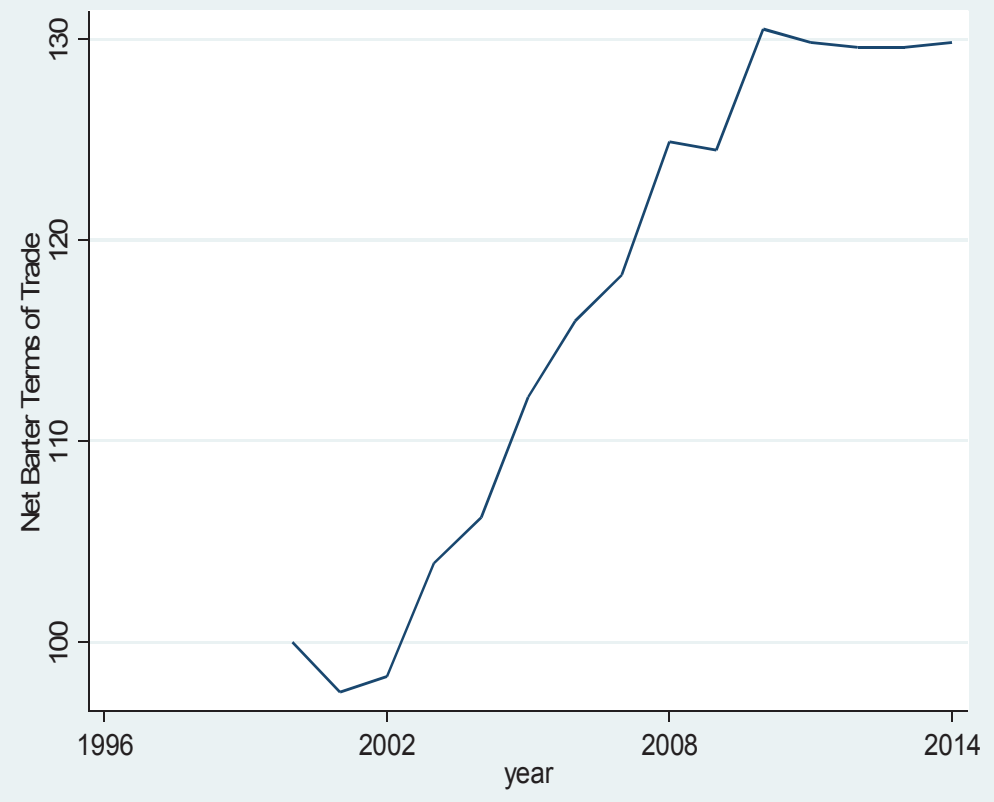


Figure 4. Exports and Imports of Specific Commodity Bundles

Panel A: Fuel
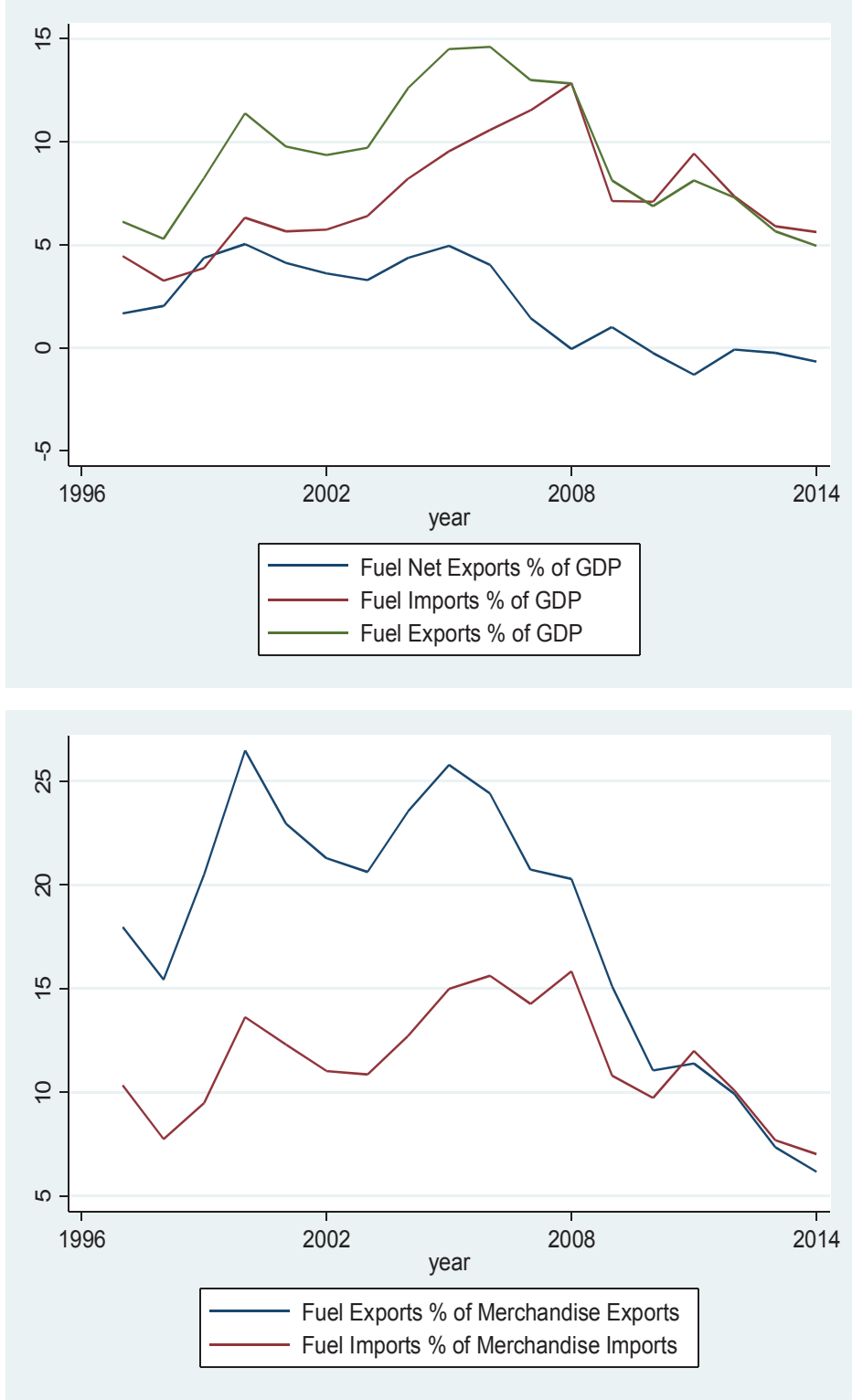
Figure 4 Exports and Imports of Specific Commodity Bundles

Panel B: Metals and Ores
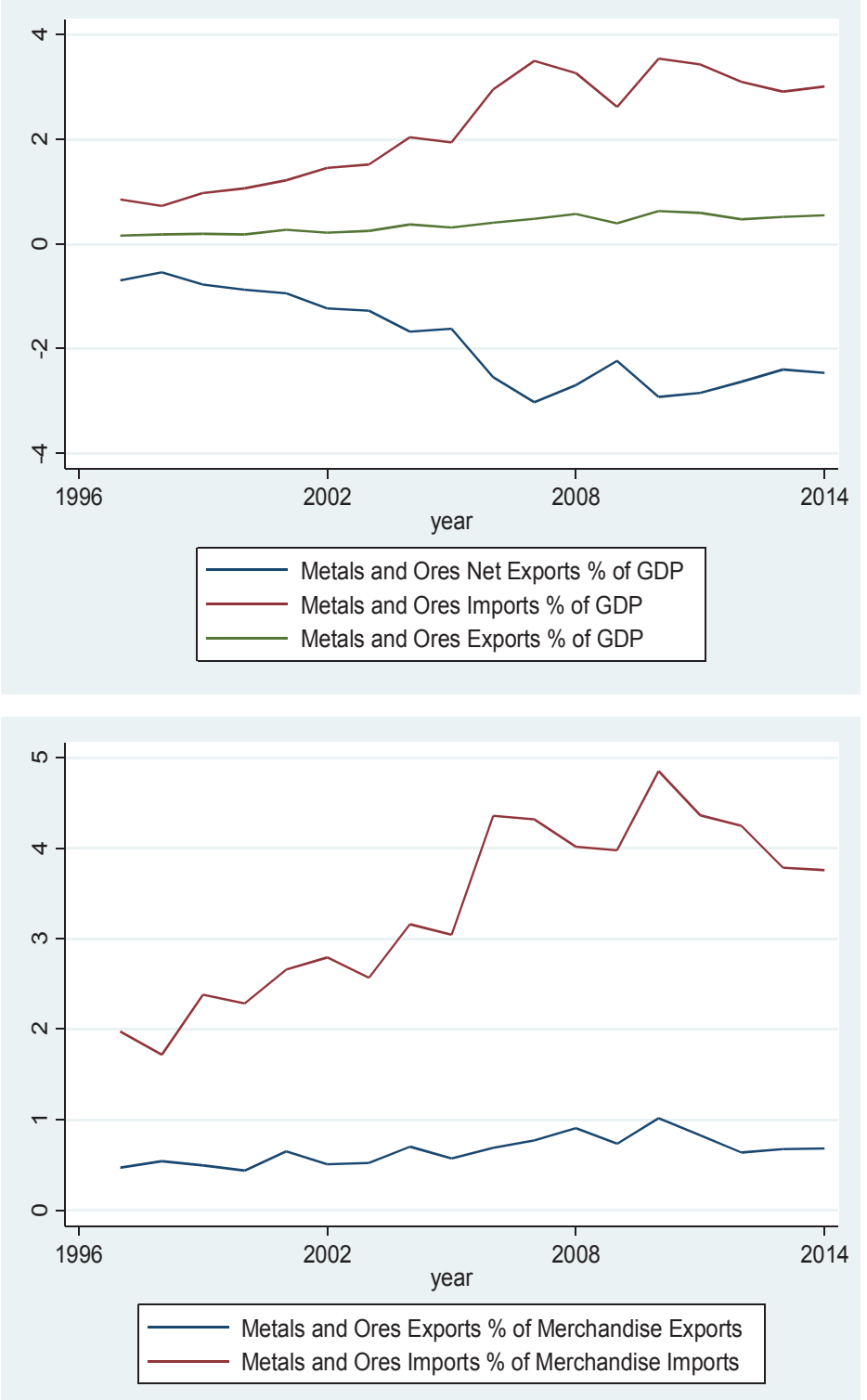
Figure 4 Exports and Imports of Specific Commodity Bundles

Panel C: Agricultural Raw Materials
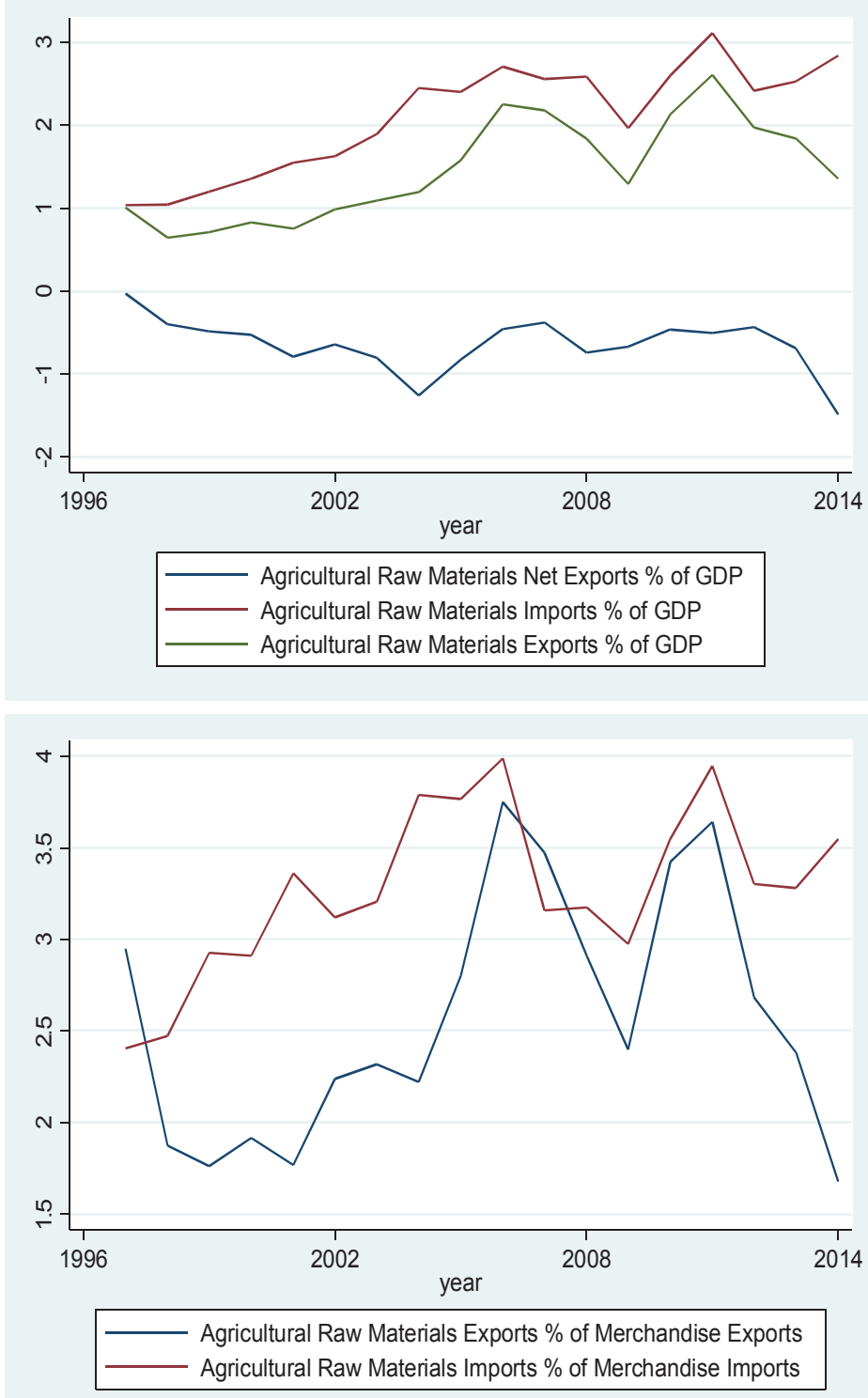
Figure 4 Exports and Imports of Specific Commodity Bundles

Panel D: Food
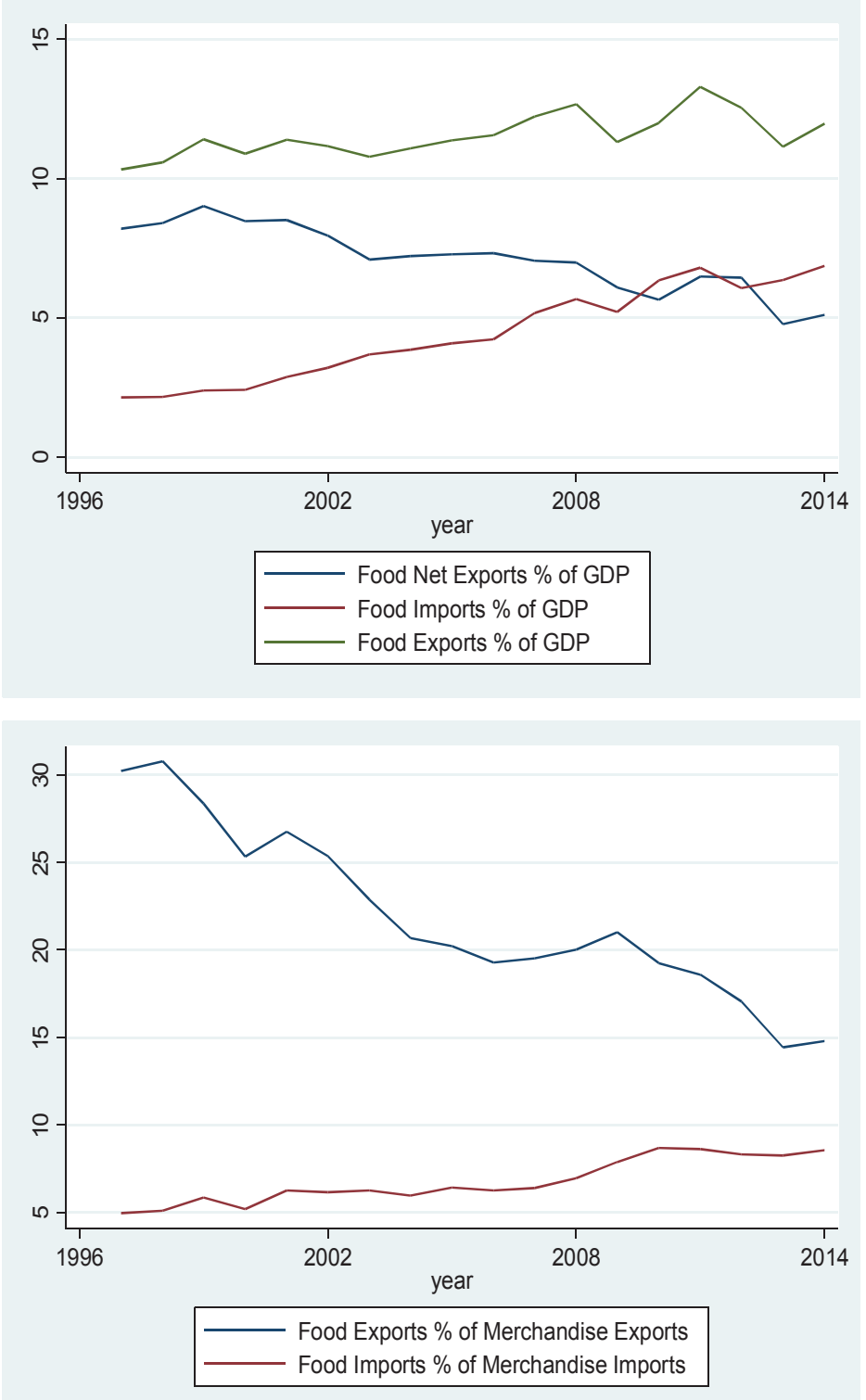
Figure 5. International Commodity Price Indices
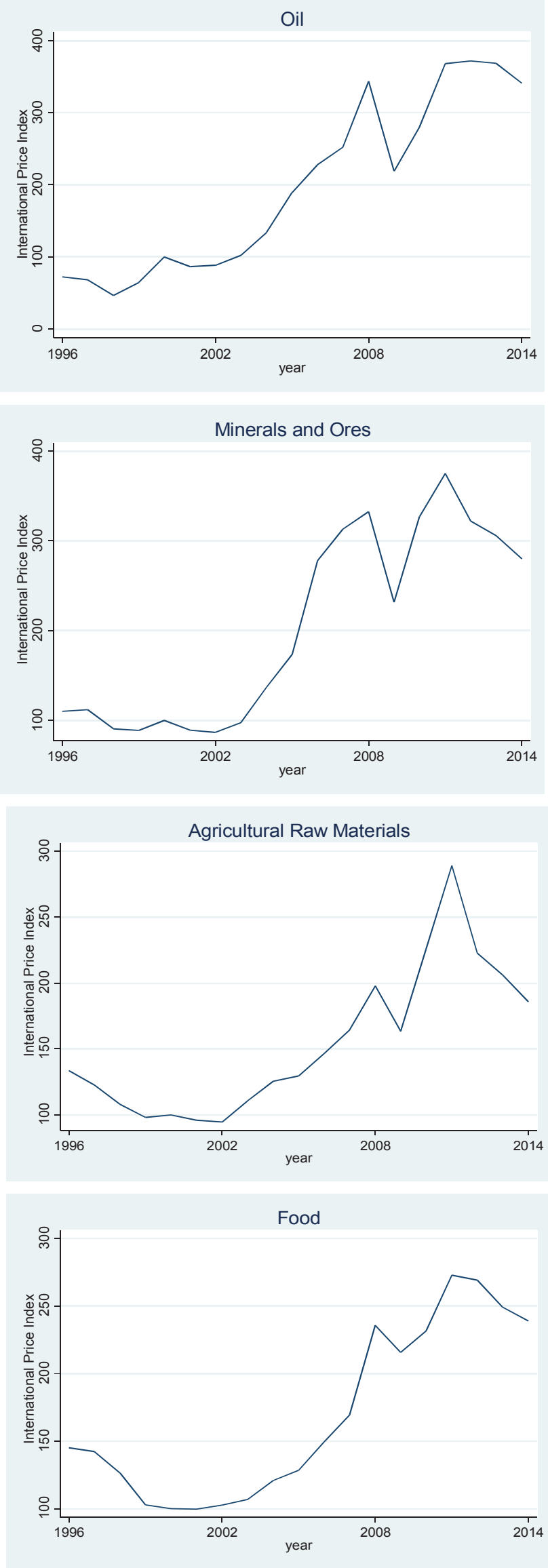
Figure 6. Year-to-Year Growth of Net-Export International Commodity Price Indices
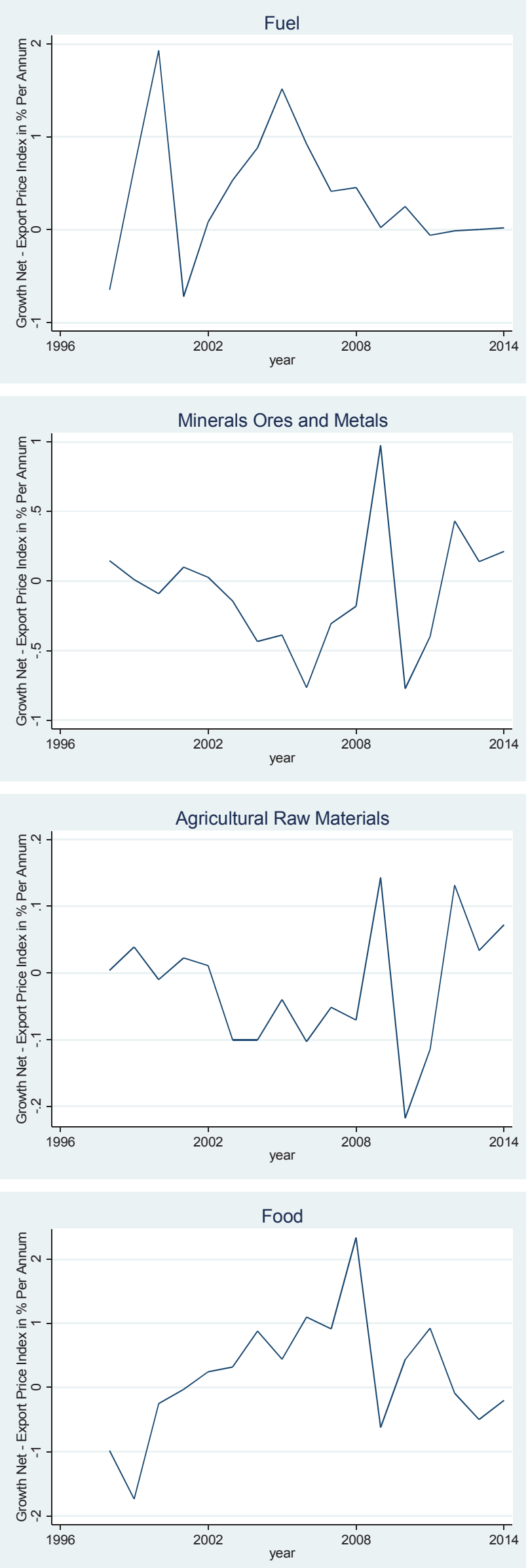
Figure 7. Year-to-Year Growth of Net-Export International Commodity Price Index

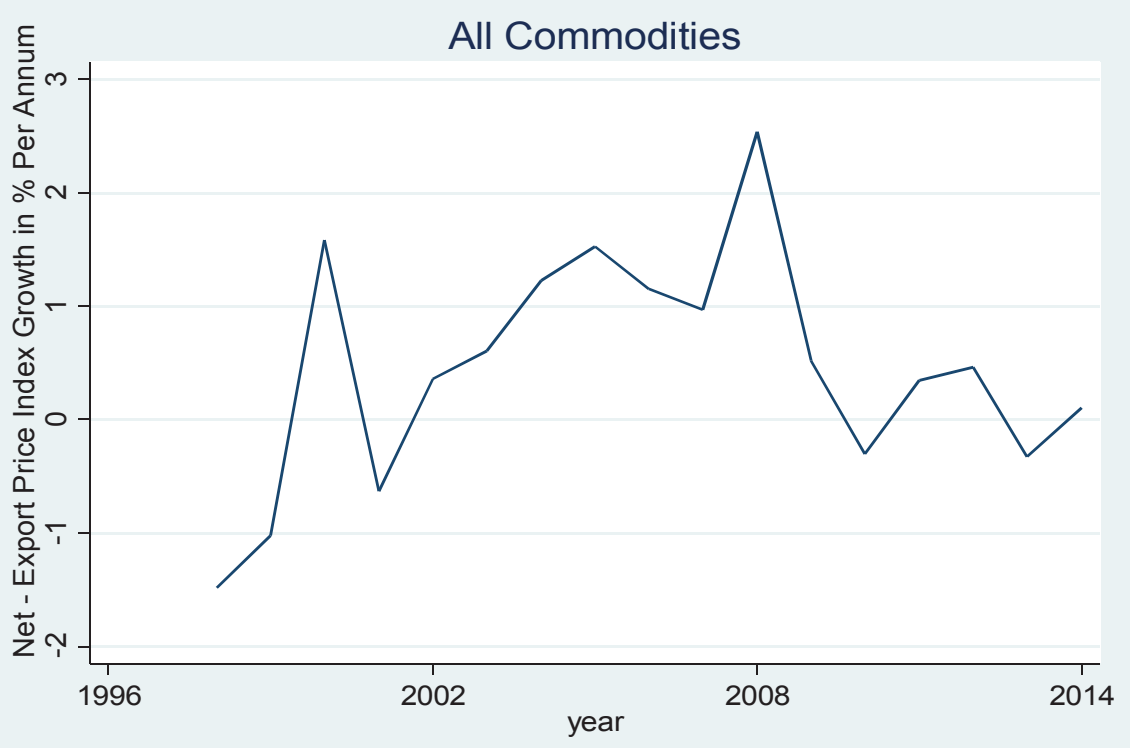


Figure 8. Year-to-Year GDP per capita Growth

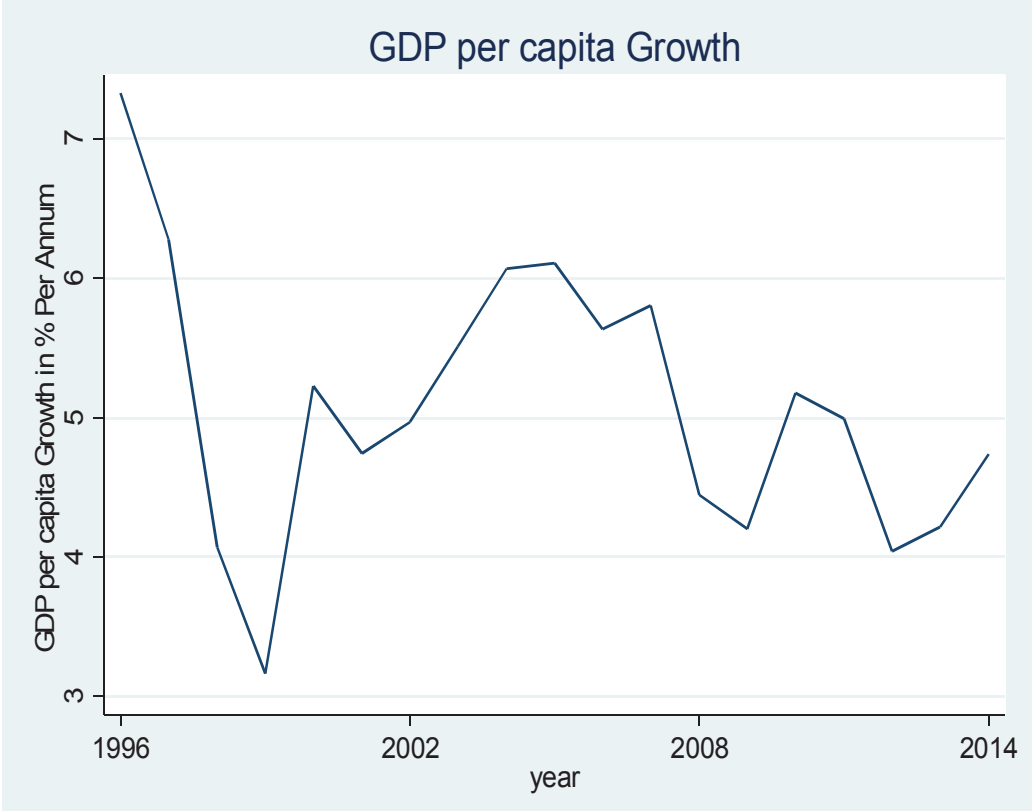


Figure 9. Growth Contribution: Transitional Convergence and Terms of Trade

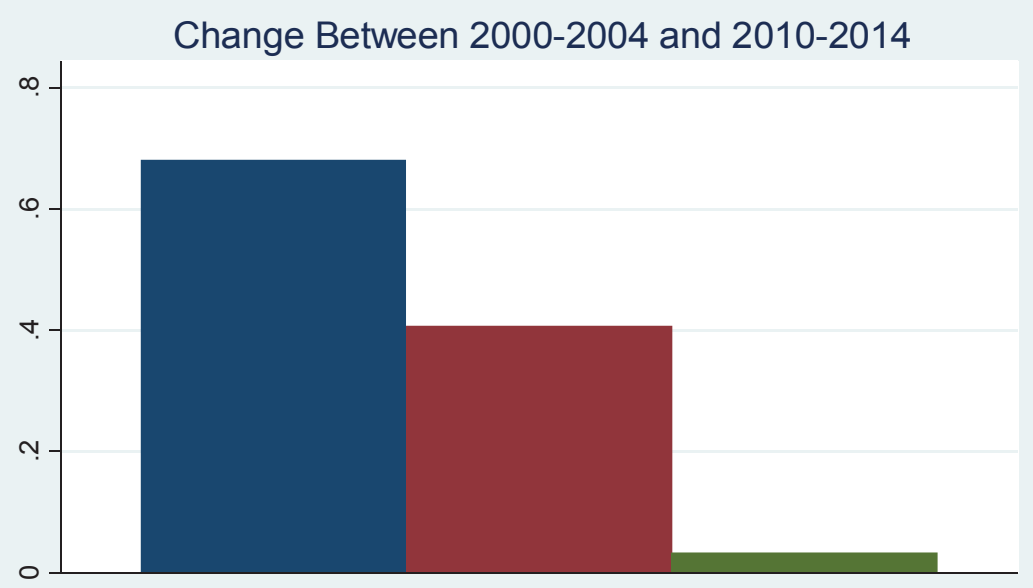

Change $\ln (G D P$ p.c.)

Contribution of Transitional Convergence

Contribution of Terms of Trade 
Appendix Table 1 Description of variables

\begin{tabular}{|c|c|}
\hline Variable & Description \\
\hline $\begin{array}{l}\text { Agricultural raw materials exports }(\% \text { of } \\
\text { merchandise exports) }\end{array}$ & $\begin{array}{l}\text { Agricultural raw materials comprise SITC } \\
\text { section } 2 \text { (crude materials except fuels) } \\
\text { excluding divisions } 22,27 \text { (crude fertilizers and } \\
\text { minerals excluding coal, petroleum, and } \\
\text { precious stones), and } 28 \text { (metalliferous ores and } \\
\text { scrap). Source WDI (2016) }\end{array}$ \\
\hline $\begin{array}{l}\text { Agricultural raw materials imports }(\% \text { of } \\
\text { merchandise imports) }\end{array}$ & $\begin{array}{l}\text { Agricultural raw materials comprise SITC } \\
\text { section } 2 \text { (crude materials except fuels) } \\
\text { excluding divisions } 22,27 \text { (crude fertilizers and } \\
\text { minerals excluding coal, petroleum, and } \\
\text { precious stones), and } 28 \text { (metalliferous ores and } \\
\text { scrap). Source WDI (2016) }\end{array}$ \\
\hline $\begin{array}{l}\text { Ores and metals exports }(\% \text { of merchandise } \\
\text { exports) }\end{array}$ & $\begin{array}{l}\text { Ores and metals comprise the commodities in } \\
\text { SITC sections } 27 \text { (crude fertilizer, minerals nes); } \\
28 \text { (metalliferous ores, scrap); and } 68 \text { (non- } \\
\text { ferrous metals). Source WDI (2016) }\end{array}$ \\
\hline $\begin{array}{l}\text { Ores and metals imports ( } \% \text { of merchandise } \\
\text { imports) }\end{array}$ & $\begin{array}{l}\text { Ores and metals comprise the commodities in } \\
\text { SITC sections } 27 \text { (crude fertilizer, minerals nes); } \\
28 \text { (metalliferous ores, scrap); and } 68 \text { (non- } \\
\text { ferrous metals). Source WDI (2016) }\end{array}$ \\
\hline Merchandise exports (current US\$) & $\begin{array}{l}\text { Merchandise exports show the value of goods } \\
\text { provided to the rest of the world valued in } \\
\text { current U.S. dollars. Source WDI (2016) }\end{array}$ \\
\hline Merchandise imports (current US\$) & $\begin{array}{l}\text { Merchandise imports show the value of goods } \\
\text { received from the rest of the world valued in } \\
\text { current U.S. dollars. Source WDI (2016) }\end{array}$ \\
\hline Fuel exports ( $\%$ of merchandise exports) & $\begin{array}{l}\text { Fuels comprise SITC section } 3 \text { (mineral fuels). } \\
\text { Source WDI (2016) }\end{array}$ \\
\hline Fuel imports ( $\%$ of merchandise imports) & $\begin{array}{l}\text { Fuels comprise SITC section } 3 \text { (mineral fuels). } \\
\text { Source WDI (2016) }\end{array}$ \\
\hline Food exports ( $\%$ of merchandise exports) & $\begin{array}{l}\text { Food comprises the commodities in SITC } \\
\text { sections } 0 \text { (food and live animals), } 1 \text { (beverages } \\
\text { and tobacco), and } 4 \text { (animal and vegetable oils } \\
\text { and fats) and SITC division } 22 \text { (oil seeds, oil } \\
\text { nuts, and oil kernels). Source WDI (2016) }\end{array}$ \\
\hline Food imports ( $\%$ of merchandise imports) & $\begin{array}{l}\text { Food comprises the commodities in SITC } \\
\text { sections } 0 \text { (food and live animals), } 1 \text { (beverages } \\
\text { and tobacco), and } 4 \text { (animal and vegetable oils } \\
\text { and fats) and SITC division } 22 \text { (oil seeds, oil } \\
\text { nuts, and oil kernels). Source WDI (2016) }\end{array}$ \\
\hline GDP, PPP (current international \$) & $\begin{array}{l}\text { Gross domestic product converted to } \\
\text { international dollars using purchasing power } \\
\text { parity rates. Source WDI (2016) }\end{array}$ \\
\hline Current account balance (\%of GDP) & $\begin{array}{l}\text { Current account balance is the sum of net } \\
\text { exports of goods and services, net primary }\end{array}$ \\
\hline
\end{tabular}




\begin{tabular}{|c|c|}
\hline & $\begin{array}{l}\text { income, and net secondary income. Source } \\
\text { WDI (2016) }\end{array}$ \\
\hline Trade ( $\%$ of GDP) & $\begin{array}{l}\text { Trade is the sum of exports and imports of } \\
\text { goods and services measured as a share of gross } \\
\text { domestic product. Source WDI (2016) }\end{array}$ \\
\hline Merchandise Exports (\% of GDP) & $\begin{array}{l}\text { Merchandise exports divided by current U.S. } \\
\text { Dollars GDP times } 100 \text {. Source WDI (2016) }\end{array}$ \\
\hline Merchandise Imports ( $\%$ of GDP) & $\begin{array}{l}\text { Merchandise imports divided by current U.S. } \\
\text { Dollars GDP times } 100 . \text { Source WDI (2016) }\end{array}$ \\
\hline Oil Price Index & $\begin{array}{l}\text { Crude petroleum, average of UK Brent (light), } \\
\text { Dubai (medium) and Texas (heavy), equally } \\
\text { weighted (\$/barrel). Source UNCTAD (2016) }\end{array}$ \\
\hline Minerals, Ores and Metals Price Index & $\begin{array}{l}\text { Minerals, ores, and metals commodity price } \\
\text { index. Source UNCTAD (2016). }\end{array}$ \\
\hline Agricultural Raw Materials Price Index & $\begin{array}{l}\text { Agricultural raw materials commodity price } \\
\text { index. Source UNCTAD (2016) }\end{array}$ \\
\hline Food Price Index & Food price index. Source UNCTAD (2016) \\
\hline Fuel Net-Export Price Index & $\begin{array}{l}\text { The index is constructed as } \delta * \ln (P) \text {, where } \delta \text { is a } \\
\text { country's average GDP share of net-exports of } \\
\text { fuels and } P \text { is the oil price index. }\end{array}$ \\
\hline $\begin{array}{l}\text { Net-Export Minerals, Ores and Metals Price } \\
\text { Index }\end{array}$ & $\begin{array}{l}\text { The index is constructed as } \delta * \ln (P) \text {, where } \delta \text { is } \\
\text { the GDP share of net-exports of minerals, ores } \\
\text { and metals and } P \text { is the minerals, ores and } \\
\text { metals price index. }\end{array}$ \\
\hline $\begin{array}{l}\text { Net-Export Agricultural Raw Materials Price } \\
\text { Index }\end{array}$ & $\begin{array}{l}\text { The index is constructed as } \delta * \ln (P) \text {, where } \delta \text { is } \\
\text { the GDP share of net-exports of agricultural raw } \\
\text { materials and } P \text { is the agricultural raw materials } \\
\text { price index. }\end{array}$ \\
\hline Net-Export Food Price Index & $\begin{array}{l}\text { The index is constructed as } \delta * \ln (P) \text {, where } \delta \text { is } \\
\text { the GDP share of net-exports of food and } P \text { is } \\
\text { the food price index. }\end{array}$ \\
\hline GDP per capita (constant 2005 US\$) & $\begin{array}{l}\text { GDP per capita is gross domestic product } \\
\text { divided by midyear population. GDP is the sum } \\
\text { of gross value added by all resident producers in } \\
\text { the economy plus any product taxes and minus } \\
\text { any subsidies not included in the value of the } \\
\text { products. It is calculated without making } \\
\text { deductions for depreciation of fabricated assets } \\
\text { or for depletion and degradation of natural } \\
\text { resources. Data are in constant } 2005 \text { U.S. } \\
\text { dollars. Source WDI (2016) }\end{array}$ \\
\hline
\end{tabular}

